\title{
Strategi Pengembangan Bisnis di Rumah Makan Batagor Baso Citamiang Spesial Bandung
}

\author{
R. R. Syifa Pertiwi Putri ${ }^{1}$, Agus Sudono ${ }^{1}$, Indriyani Handyastuti ${ }^{2}$ \\ ${ }^{1}$ Manajemen Industri Katering, Fakultas Pendidikan Ilmu Pengetahuan Sosial, Universitas \\ Pendidikan Indonesia, Jl. Dr. Setiabudhi No. 229, Bandung 40154, Indonesia \\ ${ }^{2}$ Meeting Insentif Conference Exhibition, Sekolah Tinggi Pariwisata Bandung, Jl. Dr. \\ Setiabudi No.186, Hegarmanah, Kec. Cidadap, Kota Bandung, Jawa Barat 40141
}

*Koresponding Penulis. E-mail : syifapertiwiput@gmail.com (R. R. Syifa Pertiwi Putri)

\begin{abstract}
Abstrak
Penelitian ini bertujuan untuk mengetahui faktor internal dan eksternal yang berpengaruh dalam penyusunan strategi pengembangan bisnis di Batagor Baso Citamiang Spesial. Dalam penelitian ini, penulis menggunakan metode kuantitatif kualitatif dan deskriptif. Faktor-faktor ini kemudian digunakan sebagai referensi untuk membangun strategi alternatif dalam mengembangkan Batagor Baso Citamiang Spesial. Data yang diperoleh kemudian dianalisis menggunakan matriks IFAS, matriks EFAS, matriks IE, matriks SWOT dan QSPM. Berdasarkan matriks diagram analisis SWOT, Batagor Baso Citamiang Spesial berada di kuadran empat. Posisi adalah situasi di mana perusahaan memiliki peluang dan kekuatan sehingga dapat mengambil keuntungan dari kondisi yang menguntungkan. Dengan pemikiran itu, penulis merekomendasikan strategi alternatif yang memaksimalkan kekuatan Batagor Baso Citamiang Spesial dalam memanfaatkan peluangnya. Berdasarkan hasil pengolahan data ada 14 strategi alternatif untuk pengembangan bisnis Batagor Baso Citamiang Spesial. Melalui pengolahan data menggunakan QSPM, disimpulkan bahwa strategi alternatif utama dalam pengembangan bisnis ini adalah untuk meningkatkan kualitas rasa dan berinovasi pada menu dengan mempertahankan rasa lezatnya, harga terjangkau dan kualitas yang baik dengan nilai STAS di 5.522.
\end{abstract}

Kata Kunci: Pengembangan Bisnis Restoran; Analisis SWOT; QSPM.

\section{Pendahuluan}

Saat ini semakin banyak persaingan bisnis makanan khususnya yang menjual produk bakso. Untuk tetap bisa bertahan dari pesaing-pesaing lainnya, yang harus di lakukan adalah mengembangkan dan mempertahankan ciri khas serta kenikmatan rasanya. Demikianpun dengan rumah makan Batagor Baso Citamiang Spesial ini, juga harus selalu mengembangkan strategi terbaru agar tetap bisa eksis di kalangan masyarakat, mulai dari yang muda sampai yang tua. Dalam merencanakan suatu strategi untuk mempertahankan dan mengembangkan usaha, sebuah rumah makan perlu memperhatikan beberapa hal dengan cara menganalisis data - data yang sudah ada selama beberpa waktu kebelakang, agar dapat diketahui apakah ada perkembangan, stabil atau bahkan ada penurunan dalam pendapatan. Selain itu juga harus diperhatikan mengenai kekuatan (strengths), kelemahan (weakness), peluang (opportunities) dan ancaman (threats) atau biasa disingkat menjadi SWOT. Pendapatan dari Batagor Baso Citamiang Spesial sempat mengalami kenaikan dan penurunan pendapatan yang kurang stabil di beberapa tahun ke belakang. Hal ini seharusnya tidak dialami dalam menjalankan sebuah bisnis, apalagi ketika owner menginginkan usahanya dapat berkembang dan memiliki cabang di tempat lain. Dalam jumlah pendapatan seharusnya bisa terus meningkat, walaupun perlahan tapi ada 
peningkatan terus dalam setiap tahunnya atau harus ada peningkatan yang stabil, sedangkan di Batagor Baso Citamiang Spesial ini sempat mengalami beberapa kali penurunan pendapatan. Hal ini dapat menjadi salah satu faktor internal yang dapat mempengaruhi perkembangan bisnis Batagor Baso Citamiang Spesial dan harus dilakukan perbaikan. Selain dari pendapatan, juga terdapat beberapa hal lain yang perlu di analisis untuk mendorong perkembangan bisnis, baik dari faktor internal maupun faktor eksternalnya, agar bisnis ini bisa terus bertahan bahkan bisa berkembang sesuai dengan keinginan dari owner yang ingin memiliki cabang di tempat lain.

Berdasarkan latar belakang di atas, terlihat adanya masalah dalam hal persaingan yang ketat, dan berpengaruh pada pendapatan Batagor Baso Citamiang Spesial. Yang harus dilakukan untuk mengatasi agar bisnis tersebut bisa terus bertahan dan berkembang, maka perlu adanya penelitian mengenai analisis SWOT perusahaan untuk dapat merumuskan, strategi apa yang diperlu dilakukan oleh Batagor Bakso Citamiang Spesial.

\subsection{Pengertian Pariwisata}

Secara etimologi pariwisata berasal dari dua kata yaitu "pari" yang berarti banyak atau berkeliling, sedangkan pengertian wisata berarti "pergi". Menurut UU No. 10 tahun 2009 tentang pariwisata pasal 1 menyebutkan bahwa pengertian wisata adalah kegiatan perjalanan yang dilakukan oleh seseorang atau sekelompok orang dengan mengunjungi tempat tertentu untuk tujuan rekreasi, pengembangan pribadi, atau mempelajari keunikan daya tarik wisata yang dikunjungi dalam jangka waktu sementara.

\subsection{Pengertian Wisata Kuliner}

Pengertian wisata kuliner bisa diartikan dengan sederhana seperti, jalanjalan ke tempat dimana kita bisa menikmati makanan di tempat tersebut. Untuk arti secara harfiahnya wisata adalah bepergian bersama-sama untuk memperluas pengetahuan, wawasan. Sedangkan Kuliner berarti masakan atau makanan. Jadi bisa disimpulkan bahwa wisata kuliner adalah bepergian bersama-sama untuk memperluas wawasan mengenai makanan. Berwisata memang merupakan kegiatan yang mengasyikan. Selain pengertian diatas, ICTA (International Culinary Tourism Association) memberikan pemahaman terhadap wisata kuliner yaitu, wisata kuliner suatu pencarian pengalaman wisata kuliner unik dan memberi kenangan. Sebuah pengalaman wisata kuliner yang dapat dibawa dan dirasakan dirumah.

\subsection{Pengertian Rumah Makan}

Rumah makan adalah istilah umum untuk menyebut usaha gastronomi yang menyajikan hidangan kepada masyarakat dan menyediakan tempat untuk menikmati hidangan tersebut serta menetapkan tarif tertentu untuk makanan dan pelayanannya. Menurut Wojowasito dan Poerwodarminto (Marsya, 1999:71) mengklasifikasikan restoran atau rumah makan menjadi beberapa tipe, antara lain A'la Carte Restaurant, Table D hote Restaurant, Coffee Shop atau Brasserei, Cafetaria atau Cafe, Canteen, Continental Restaurant, Carvery, Dining Room, Discotheque, Fish and Chip Shop, Night Club/Super Club, Pub, Gourmet Restoran, Family Type Restaurant, Main Dining Room.

\subsection{Pengertian Manajemen}

Strategi adalah rencana yang disatukan, luas dan berintegrasi yang menghubungkan keunggulan strategis perusahaan dengan tantangan lingkungan, yang dirancang untuk memastikan bahwa tujuan utama dari perusahaan dapat dicapai melalui pelaksanaan yang tepat oleh organisasi (Glueck dan Jauch : 1989).

\subsection{Pengertian Manajemen Strategi \\ Menurut Siagian}


mendefinisikan manajemen stratejik merupakan serangkaian keputusan dan tindakan mendasar yang dibuat oleh manajemen puncak dan diimplementasikan oleh seluruh jajaran suatu organisasi dalam rangka pencapaian tujuan organisasi tersebut.

\subsection{Tujuan Manajemen Strategi}

Strategi yang dikembangkan perusahaan melalui proses manajemen strategik bertujuan untuk menciptakan keunggulan kompetitif bagi perusahaan. Beberapa indikator yang dapat dijadikan acuan untuk indikator kinerja akutansi dan kinerja ekonomi (Barney dan Hasterly, 2008). Melalui analisis terhadap laporan keuangan sebuah perusahaan, maka akan diperoleh informasi mengenai kinerja akutansi sebuahperusahaan baik dilihat dari sisi profitabilitas maupun rasio - rasio keuangan. Dengan membandingkan kinerja akutansi sebuah perusahaan dengan perusahaan - perusahaan lainnya dalam satu industri, maka akan dapat diperoleh gambaran mengenai kinerja perusahaan dibandingkan pesaing, yakni apakah perusahaan memiliki keunggulan kompetitif ataukan tidak.

\subsection{Manfaat Manajemen Strategi}

Dengan menggunakan manajemen strategik sebagai suatu kerangka kerja (frame work) untuk menyelesaikan setiap masalah strategis di dalam organisasi terutama berkaitan dengan persaingan, maka peran manajer diajak untuk berpikir lebih kreatif atau berpikir secara strategik. Proses Manajemen Strategi

Seperti yang telah dijelaskan sebelumnya, pada intinya manajemen strategi itu adalah proses untuk menghasilkan berbagai keputusan dan tindakan yang akan menunjang pencapaian tujuan perusahaan. Berikut ini adalah langkah - langkah dalam proses manajemen strategi:
a. Perumusan
Strategi
(Strategy
b. Implementasi Strategi
(Strategy
Implemented)
c. Evaluasi Strategi (Strategy Evaluation)

1.8. Tingkatan - Tingkatan Strategi Dengan merujuk pada pandangan Dan

Schendel dan Charles Hofer, Higgins (1985) menjelaskan adanya empat tingkatan strategi. Keseluruhannya disebut Master Strategy, yaitu:

a. Strategi Tingkat Oranisasi

b. Strategi Tingkat Korporasi

c. Strategi Tingkat Satuan Bidang Bisnis

d. Strategi Tingkat Fungsional

\subsection{Visi, Misi dan Tujuan}

Tiga hal yang selalu menjadi perhatian dalam setiap melakukan tahap awal analisis SWOT, yaitu meninjau visi, misi, dan tujuan untuk merumuskan suatu strategi secara efektif.

\subsection{Analisis Lingkungan Internal}

Analisis lingkungan internal adalah analisis secara internal perusahaan dalam rangka menilai atau mengidentifikasikan kekuatan (strength) dan kelemahan (weakness) dari perusahaan tersebut. Dalam penelitian ini akan menganalisis beberapa hal untuk melihat keadaan perusahaan secara internal, diantaranya seperti, product, price, place, promotion, marketing, finansial.

\subsection{Analisis Lingkungan Eksternal}

Analisis lingkungan eksternal adalah faktor - faktor yang merupakan kekuatan yang berada di lingkungan luar perusahaan, dimana perusahaan tidak mempunyai pengaruh langsung terhadap kehidupan suatu bisnis. Perubahan - perubahan yang terjadi pada lingkungan ini secara tidak langsung akan mempengaruhi kinerja perusahaan dalam suatu hubungan timbal balik. Lingkungan eksternal mengandung dua faktor yaitu peluang (opportunities) dan ancaman (threats). Analisis ini memiliki pengaruh yang sangat kuat, menyebabkan 
perlunya perhatian lebih terhadap dimensi atau aspek yang terkandung di dalamnya, meskipun berada di luar lingkungan perusahaan. Beberapa hal yang perlu diperhatikan dari lingkungan eksternal ini adalah dari segi politik, ekonomi, sosial budaya, dan teknologi

\section{Metode Penelitian}

\subsection{Kerangka Pemikiran}

Saat ini sudah semakin banyak pelaku bisnis yang mencoba peruntungannya didalam bisnis kuliner. Hal ini dapat berpengaruh pada intensitas persaingan menjadi semakin ketat. Faktor - faktor yang paling penting untuk diperhatikan oleh sebuah perusahaan dalam melihat masa depan adalah SWOT, merupakan singkatan dari Strength (kekuatan), Weakness (kelemahan), Opportunities (kesempatan), dan Threats (ancaman). Setelah mengidentifikasi faktor - faktor strategis, manajemen mengevaluasi interaksinya dan menentukan misi perusahaan yang sesuai. Langkah pertama dalam merumuskan strategi adalah pernyataan misi, yang berperan penting dalam menentukan tujuan, strategi, dan kebijakan perusahaan, yang pada akhirnya akan ada evaluasi kerja dan umpan balik untuk memastikan tepatnya pengendalian aktivitas perusahaan.

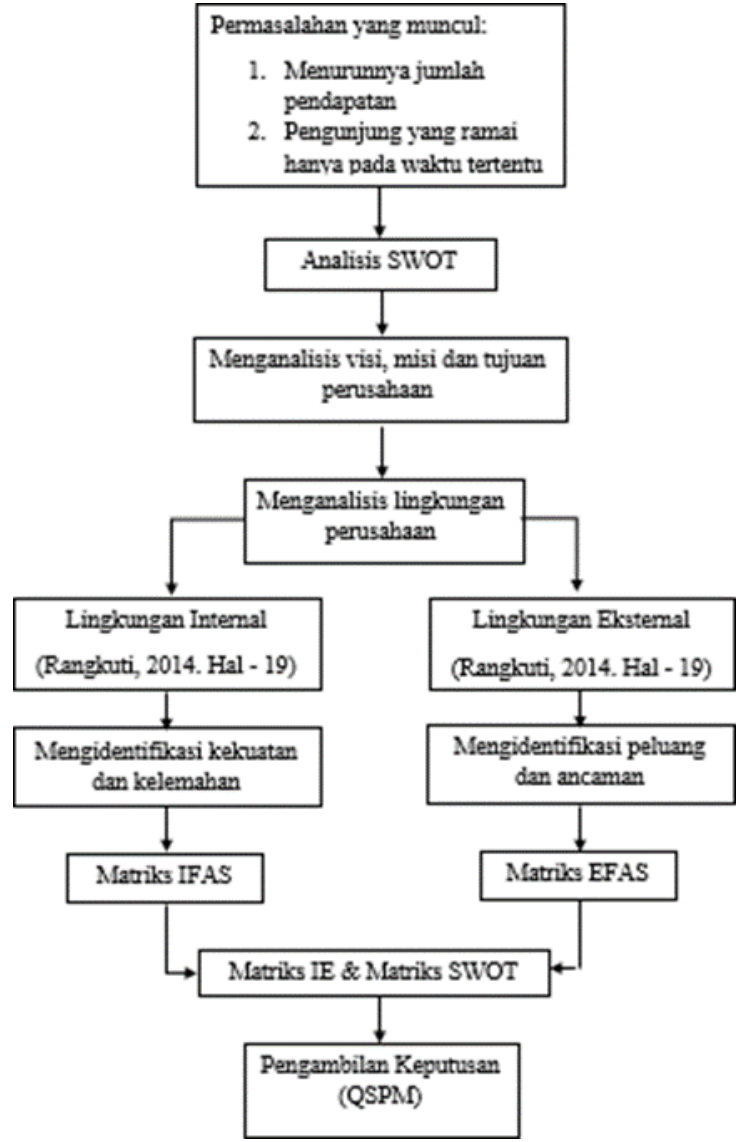

Sumber : Data Diolah Penulis, 2018

Gambar 1. Kerangka Pemikiran Analisis SWOT Dalam Meningkatkan Pendapatan Batagor Baso Citamiang Spesial

\subsection{Metode Penelitian}

Menurut Sugiono (2012, Hal-2) mendefinisikan metode penelitian adalah cara ilmiah untuk mendapatkan data dengan tujuan dan kegunaaan tertentu. Dalam pengertian yang luas, metode penelitian adalah cara - cara ilmiah untuk mendapatkan data yang valid, dengan tujuan dapat ditemukan, dikembangkan dan dibuktikan, suatu pengetahuan tertentu sehingga suatu ketika dapat digunakan untuk memahami, memecahkan dan mengantisipasi masalah.

Metode yang hasil dari perhitungan angka yang sebelumnya telah di olah terlebih dahulu.

\subsection{Informan Penelitian}

Incidental sampling akan digunakan 
dalam analisis penelitian kualitatif dengan metode nonprobability sampling. Incidental sampling ini adalah teknik penentuan sampel berdasarkan kebetulan, yaitu siapa saja yang secara kebetulan atau insidental bertemu dengan peneliti dapat digunakan sebagai sampel, bila dipandang orang yang kebetulan ditemui itu cocok dengan sumber data. Yang menjadi informan dalam penelitian ini yaitu owner Batagor Baso Citamiang Spesial yang akan di wawancarai mengenai faktor internal dan faktor eksternal yang dapat mempengaruhi pendapatan di Batagor Baso Citamiang Spesial. Penyebaran kuesioner ini dilakukan untuk memperkuat faktor internal apa saja yang selama ini berpengaruh pada bisnis Batagor Baso Citamiang Spesial.

\subsection{Sampel}

Menurut Martono (2011, Hal-80) bila jumlah populasi banyak misalnya lebih dari 500 orang atau bahkan sampai 1000 orang, maka tidak mungkin mengambil semua anggota populasi sebagai sampel. Di dalam penelitian ini akan menggunakan beberapa sampel sebanyak 100 orang konsumen dari hasil pembulatan angka 97 dan terdapat juga perwakilan empat orang karyawan dari Batagor Baso Citamiang Spesial serta, satu orang owner untuk di wawancara agar dapat mengetahui faktor - faktor SWOT apa saja yang dapat mempengaruhi bisnis ini. Berikut ini adalah perhitungannya dalam menentukan jumlah sampel konsumen Batagor Baso Citamiang Spesial.

$$
\begin{gathered}
n=\frac{N}{1+N(e)^{2}} \\
=\frac{3154}{1+3154(0,1)^{2}} \\
n=97
\end{gathered}
$$

\subsection{Teknik Sampling}

Teknik sampling menurut Sugiono (2012, Hal-116) merupakan teknik pengambilan sampel. Dalam menentukan sampel penelitian, terdapat beberapa teknik sampling yang dapat digunakan. Teknik sampling ini pada dasasrnya dapat dikelompokkan menjadi dua yaitu Probability Sampling dan nonproability Sampling. Probability Sampling meliputi simple ramdom, proportionate stratifed ramdom, disproportionate stratified ramdom dan area random. Sedangkan Nonprobability sampling meliputi sampling sistematis, sampling kuota, sampling aksidental atau insidental, purposive sampling, snowball sampling dan sampling jenuh. Penelitian ini menggunakan teknik sampling insidental yaitu penentuan sampel berdasarkan kebetulan, atau siapa saja yang secara kebetulan atau secara insidental bertemu dengan peneliti dan dapat digunakan sebagai sampel, bila dipandang orang yang kebetulan di temui itu cocok sebagai sumber data.

Berdasarkan sumber data yang telah di dapatkan, maka pengumpulan data dapat menggunakan sumber data primer dan sumber data sekunder.

Tabel 1. Jenis dan Sumber Data

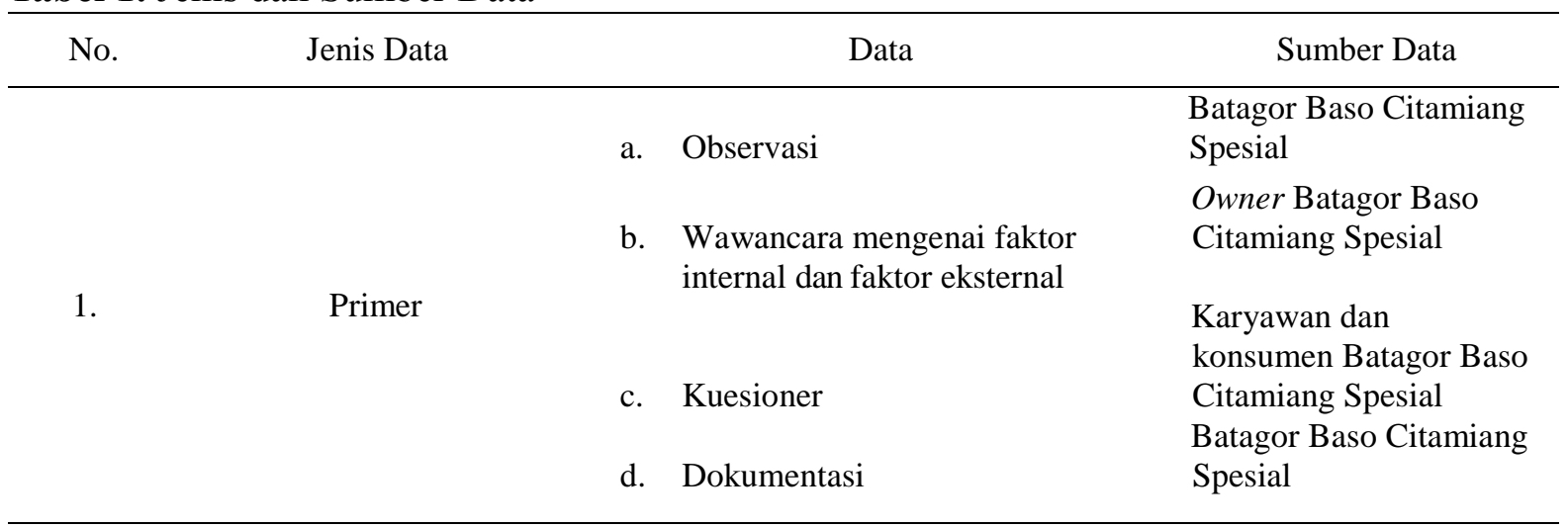




\begin{tabular}{cccl}
\hline No. & Jenis Data & Data & \multicolumn{1}{c}{ Sumber Data } \\
\hline & & \\
& & $\begin{array}{l}\text { Karya ilmiah, artikel, } \\
\text { media internet, buku, } \\
\text { data perusahaan Batagor } \\
\text { Baso Citamiang } \\
\text { Spesial. }\end{array}$ \\
\hline Sumber : Data Diolah Penulis, 2017 & $\begin{array}{l}\text { Teori berdasarkan variabel yang akan } \\
\text { diteliti. }\end{array}$ & \\
& &
\end{tabular}

Teknik sampling dalam penelitian ini menggunakan metode nonprobability sampling yaitu insidental sampling dan purposive sampling (Sugiyono, 2009). Teknik sampling insidental ini di gunakan pada penelitian bertujuan untuk mengetahui penilaian terhadap faktor internal dan beberapa faktor eksternal dari Batagor Baso Citamiang Spesial. Penelitian ini menggunakan teknik sampling insidental yaitu penentuan sampel berdasarkan kebetulan, atau siapa saja yang secara kebetulan atau secara insidental bertemu dengan peneliti dan dapat digunakan sebagai sampel, bila dipandang orang yang kebetulan di temui itu cocok sebagai sumber data.

\section{Hasil dan Pembahasan}

Pada penelitian kualitatif, data yang diperoleh dari berbagai sumber, dengan menggunakan teknik pengumpulan data yang bermacam - macam atau secara triangulasi dan dilakukan terus menerus sampai datanya jenuh. Patton (2007, Hal103) menjelaskan bahwa analisis data adalah proses mengatur urutan data, mengorganisasikanya ke dalam suatu pola, kategori, dan satuan uraian dasar.

\subsection{Tahap Input}

\section{a. Analisis Matriks IFAS}

Setelah faktor - faktor strategis internal dari Batagor Baso Citamiang Spesial di identifikasi, penyusunan tabel IFAS akan berfungsi untuk merumuskan faktor - faktor strategis internalnya dalam kerangka Strength (kekuatan) dan Weakness (kelemahan). Dalam tabel IFAS ini, menurut Freddy Rangkuti (2014, Hal-27) akan di berikan bobot dengan skala mulai dari 1,0 paling penting, sampai 0,0 tidak penting, serta akan di beri rating oleh peneliti dengan skala mulai dari 4 (outstanding) sampai dengan 1 (poor).

Tabel 2. Matriks IFAS

\begin{tabular}{|c|c|c|c|c|}
\hline $\begin{array}{c}\text { No } \\
\text {. }\end{array}$ & Faktor Strategi Internal & Bobot & Rating & Score \\
\hline & \multicolumn{4}{|c|}{ Strengths (kekuatan) } \\
\hline 1. & Harga yang murah & 0,050 & 4 & 0,200 \\
\hline 2. & Rasa yang lezat & 0,050 & 4 & 0,200 \\
\hline 3. & $\begin{array}{l}\text { Memiliki keunggulan produk } \\
\text { dibandingkan dengan rumah makan } \\
\text { lain yang sejenis }\end{array}$ & 0,038 & 3 & 0,114 \\
\hline 4. & Memiliki target pasar yang luas & 0,050 & 4 & 0,200 \\
\hline 5. & Menu yang beragam & 0,038 & 3 & 0,114 \\
\hline 6. & $\begin{array}{l}\text { Kualitasnya baik, masih terlitah fresh } \\
\text { saat disajikan }\end{array}$ & 0,050 & 4 & 0,200 \\
\hline 7. & Lokasi yang cukup mudah di jangkau & 0,038 & 3 & 0,114 \\
\hline 8. & Tempatnya bersih & 0,050 & 4 & 0,200 \\
\hline
\end{tabular}




\begin{tabular}{|c|c|c|c|c|}
\hline No & Faktor Strategi Internal & Bobot & Rating & Score \\
\hline 9. & $\begin{array}{l}\text { Memiliki tata tertib } \\
\text { kerja karyawan }\end{array}$ & 0,038 & 3 & 0,114 \\
\hline 10. & Memiliki $\quad$ standar resep & 0,050 & 4 & 0,200 \\
\hline 11. & $\begin{array}{l}\text { Memiliki kebijakan } \\
\text { untuk karyawan }\end{array}$ & 0,050 & 4 & 0,200 \\
\hline 12. & $\begin{array}{l}\text { Memiliki tata cara } \\
\text { dalam melayani tamu }\end{array}$ & 0,038 & 3 & 0,114 \\
\hline 13. & $\begin{array}{l}\text { Pelayanan yang } \\
\text { ramah }\end{array}$ & 0,050 & 4 & 0,200 \\
\hline 14. & $\begin{array}{l}\text { Pelayanan yang cukup } \\
\text { cepat }\end{array}$ & 0,038 & 3 & 0,114 \\
\hline 15. & $\begin{array}{l}\text { Luasnya peluang kerja di Batagor } \\
\text { Baso Citamiang Spesial }\end{array}$ & 0,050 & 4 & 0,200 \\
\hline 16. & Tidak memiliki hutang & 0,050 & 4 & 0,200 \\
\hline \multicolumn{5}{|c|}{ Weakness (kelemahan) } \\
\hline 1. & $\begin{array}{l}\text { Kurangnya pemanfaatan berbagai } \\
\text { media promosi }\end{array}$ & 0,025 & 2 & 0,050 \\
\hline 2. & $\begin{array}{l}\text { Tempat parkir yang } \\
\text { kurang luas }\end{array}$ & 0,010 & 1 & 0,010 \\
\hline 3. & $\begin{array}{l}\text { Tidak adanya lahan } \\
\text { parkir untuk mobil }\end{array}$ & 0,010 & 1 & 0,010 \\
\hline 4. & $\begin{array}{l}\text { Fasilitas yang sedikit kurang } \\
\text { memenuhi kebutuhan konsumen }\end{array}$ & 0,038 & 3 & 0,114 \\
\hline 5. & $\begin{array}{l}\text { Penulisan pendapatan per-hari, } \\
\text { perbulan dan per-tahun masih di tulis } \\
\text { tangan dalam sebuah buku }\end{array}$ & 0,038 & 3 & 0,114 \\
\hline 6. & Tidak ada organisasi karyawan & 0,038 & 3 & 0,114 \\
\hline 7. & $\begin{array}{l}\text { Tidak memiliki } \\
\text { ketetapan sanksi untuk setiap point }- \\
\text { point peraturan jika ada karyawan } \\
\text { yang } \\
\text { melanggar }\end{array}$ & 0,038 & 3 & 0,114 \\
\hline \multirow[t]{2}{*}{8.} & $\begin{array}{l}\text { Belum memiliki } \\
\text { Strategi penjualan } \\
\text { Sendiri dalam mengembangkan } \\
\text { bisnisnya }\end{array}$ & 0,025 & & 0,050 \\
\hline & Total & 1 & & 3,460 \\
\hline
\end{tabular}

Sumber : Data Diolah Penulis, 2018

Berdasarkan hasil analisis matriks IFAS tersebut dapat di ketahui bahwa pada faktor strength (kekuatan) yang memiliki nilai skor tersebesar adalah sebesar 0,2 dan untuk faktor weakness (kelemahan) memiliki nilai skor terbesar adalah 0,114 . Maka, dapat di simpulkan dari matriks IFAS ini strength (kekuatan) mempunyai kemampuan lebih tinggi dari pada weakness (kelemahan) dalam menentukan strategi untuk mengembangkan bisnis ini. b. Analisis Matriks EFAS

Langkah berikutnya dalam penyusunan strategi adalah menganalisis melalui matriks EFAS. Seperti pada matriks sebelumnya yaitu matriks IFAS dalam pembobotan dan pemberian rating menurut Freddy Rangkuti (2014, Hal-27) bobot dengan skala mulai dari 1,0 paling penting, sampai 0,0 tidak penting, serta rating dengan skala mulai dari 4 (outstanding) sampai dengan 1 (poor). Berikut ini adalah tabel matriks EFAS. 
Tabel 3. Matriks EFAS

\begin{tabular}{|c|c|c|c|c|}
\hline No. & Faktor Strategi Eksternal & Bobot & Rating & Score \\
\hline \multicolumn{5}{|c|}{ Opportunities (Peluang) } \\
\hline 1. & $\begin{array}{l}\text { Sudah memiliki SIUP dan } \\
\text { Sertifikat Halal }\end{array}$ & 0,180 & 4 & 0,720 \\
\hline 2. & $\begin{array}{l}\text { Tidak mengikuti kebijakan pemerintah dalam } \\
\text { pinjaman koperasi sehingga terhindar dari hutang }\end{array}$ & 0,090 & 2 & 0,180 \\
\hline 3. & $\begin{array}{l}\text { Menggaji karyawannya sesuai UMR dan sesuai } \\
\text { lama bekerja karyawan }\end{array}$ & 0,140 & 3 & 0,420 \\
\hline 4. & $\begin{array}{l}\text { Penggunaan teknologi modern dalam } \\
\text { pembuatan mie dan baksonya }\end{array}$ & 0,180 & 4 & 0,720 \\
\hline 5. & $\begin{array}{l}\text { Naik turunnya perekonomian di Kota Bandung } \\
\text { tidak berpengaruh besar terhadap bisnis ini }\end{array}$ & 0,140 & 3 & 0,420 \\
\hline \multicolumn{5}{|c|}{ Threats (Ancaman) } \\
\hline 1. & $\begin{array}{l}\text { Masih ada beberapa karyawan yang belum di beri } \\
\text { tahu jelas mengenai ketentuan dan perhitungan } \\
\text { jumlah gajinya }\end{array}$ & 0,045 & 1 & 0,045 \\
\hline 2. & $\begin{array}{l}\text { Semakin banyaknya tren makanan masa kini yang } \\
\text { dapat mengalihkan konsumennya untuk lebih } \\
\text { memilih makanan dan minuman yang lebih } \\
\text { kekinian }\end{array}$ & 0,045 & 1 & 0,045 \\
\hline 3. & $\begin{array}{l}\text { Belum melakukan inovasi } \\
\text { makanan lagi secara rutin }\end{array}$ & 0,090 & 2 & 0,180 \\
\hline \multirow[t]{2}{*}{4.} & $\begin{array}{l}\text { Belum bargabung dengan pemesanan dari jasa } \\
\text { ojek online yang dapat memudahkan konsumen } \\
\text { dalam pemesanan }\end{array}$ & 0,090 & 2 & 0,180 \\
\hline & Total & 1 & & 2,910 \\
\hline
\end{tabular}

Sumber : Data Diolah Penulis, 2018

Dapat dilihat pada tabel matriks EFAS bahwa terdapat opportunity (peluang) yang memiliki nilai skor sebesar 0,72 dan sedangkan pada threat (ancaman) memiliki nilai skor sebesar 0,18 . Hal ini menunjukan bahwa bisnis ini memiliki opportunity (peluang) yang lebih besar dari pada threat (ancaman) dalam penyusunan strategi pengembangan bisnis ini.

c. Analisis Matrik IE (Internal-Eksternal)

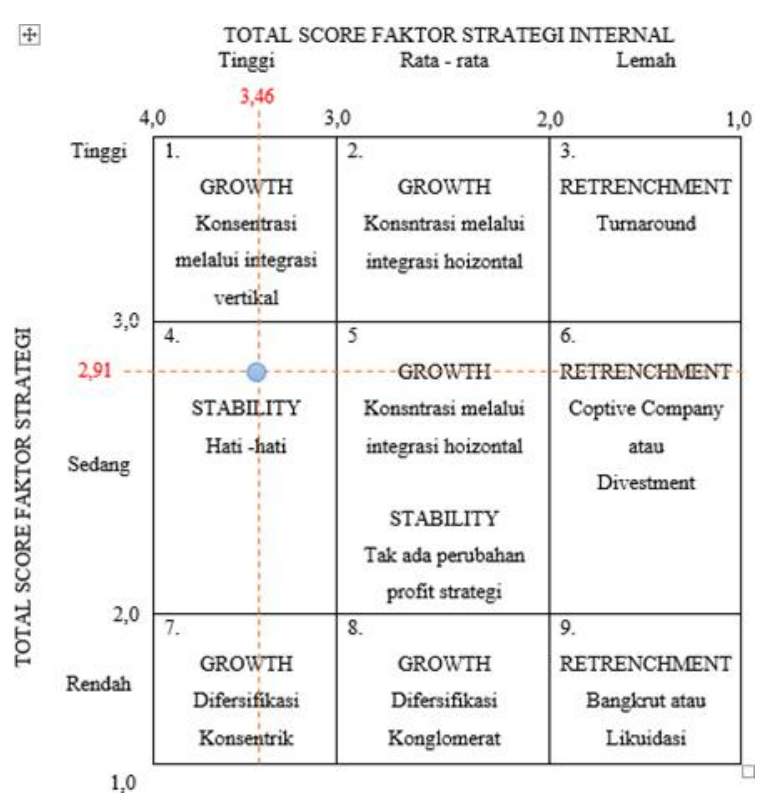

Sumber : Data Diolah Penulis, 2018

Gambar 2. Matrik IE

Matriks IE yaitu menyusun strategi yang terbagi ke dalam sembilan sel. Tolak 
ukur yang digunakan adalah kekuatan kekuatan internal dari IFAS untuk garis horizontalnya dan peluang ancaman dari EFAS untuk garis vertikal.

Dari hasil analisis matriks IFAS di dapatkan total nilai sebesar 3,46 yang berarti bisnis ini dapat memanfaatkan kekuatannya dan mengatasi kelemahannya dengan baik, dan dari matriks EFAS setelah di analisis di dapatkan nilai total sebesar 2,91 yang emnunjukkan bahwa bisnis ini dapat memanfaatkan peluangnya dengan baik dan mengatasi ancaman yang ada. Pada matriks IE tersebut, dapat di lihat Batagor Baso Citamiang Spesial berada pada sel 4, dapat di gambarkan sebagai tumbuh dan membangun. Strategi yang intensif seperti penetrasi pasar, pengembangan pasar, dan pengembangan produk dapat di lakukan pada bisnis ini (Rangkuti, 2011:344).

d. Diagram SWOT

Untuk lebih jelasnya kuadran analisis SWOT berikut ini dapat memperjelas dimana posisi Batagor Baso Citamiang Spesial, dan berikut ini adalah hasilnya

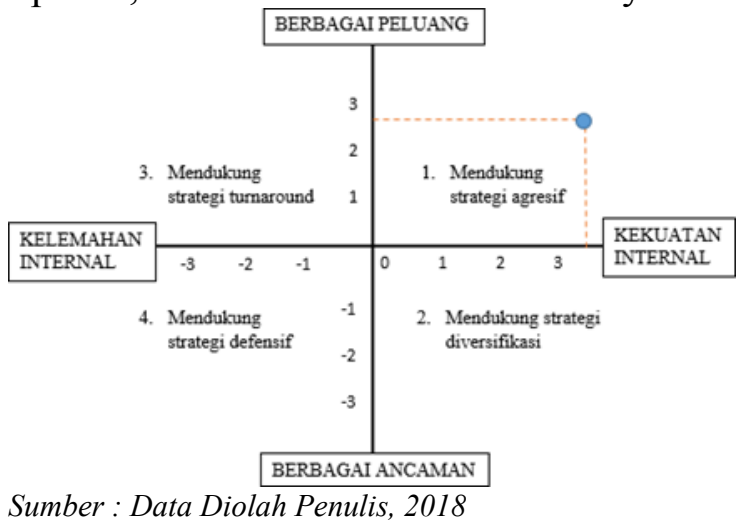

Gambar 3. Diagram Analisis SWOT

Dari diagram tersebut dapat diketahui bahwa posisi Batagor Baso Citamiang Spesial berada di kuadran 1. Menurut Freddy Rangkuti (2014, Hal-20) posisi ini merupakan situasi yang sangat menguntungkan. Perusahaan tersebut memiliki peluang dan kekuatan sehingga dapat memanfaatkan peluang yang ada. Strategi yang harus di terapkan adalah mendukung kebijakan pertumbuhan yang agresif (growth oriented strategy).

e. Matriks SWOT
Matriks SWOT adalah alat yang di pakai untuk menyusun faktor - faktor strategis perusahaan. Matriks ini dapat menggambarkan secara jelas bagaimana peluang dan ancaman eksternal yang di hadapi perusahaan dapat di sesuaikan dengan kekuatan dan kelemahan yang di milikinya (Rangkuti, 2014:83).

Berdasarkan dari analisis natriks SWOT, didapatkan beberapa strategi yaitu seperti yang akan di uraikan di bawah ini.

1) Strategi SO

o Memperluas pemasaran

o Mengembangkan menu

o Mengelola keuangan lebih baik lagi

o Menambah variasi menu

2) Strategi ST

o Meningkatkan kualitas rasa dan melakukan inovasi baru pada menu

oMeningkatkan

kenyamanan

karyawan dalam bekerja

o Melakukan inovasi menu baru dengan menggunakan standar resep dan meningkatkan kebersihan o Meminimalisir pengeluaran

3) Strategi WO

o Memperbanyak promosi melalui berbagai media promosi online o Membuat organisasi karyawan dengan tugasnya masing - masing o Memperbaiki sistem pembukuan keuangan

4) Strategi WT

o Melakukan efesiensi transaksi di tempat dengan jasa pesan antar atau melalui ojek online

o Memperbaiki pembukuan data keuangaan dan pengeluaran uang kas agar keuangan perusahaan dapat terperhatikan betul oleh owner

o Mengadakan organisasi karyawan dengan bagian keuangan dan membuat sistem keuangan di yang di dalamnya terdapat jumlah pendapatan perhari, pengeluaran yang di lakukan (untuk apa saja dan keteangan jenis \& jumlahnya untuk pembelian barang) dan jumlah saldo 


\section{keuangannya secara otomatis \\ f. Matriks QSPM \\ Matriks QSPM akan di peroleh dari} nilai STAS yang di dapatkan dari perkalian bobot faktor internal dan faktor eksternal Batagor Baso Citamiang Spesial beerdasarkan matriks IFAS dan EFAS dengan nilai AS (Alternative Score) pada setiap alternatif strategi yang akan menghasilkan nilai TAS (Total Alternative Score). Selanjutnya nilai TAS di jumlahkan seluruhnya dari setiap alternatif strategi dan dari situ lah nilai STAS dapat di ketahui. Untuk penilaian pada tahap penentuan alternatif strategi di lakukan oleh peneliti. Berikut ini adalah hasil dari perhitungan masing - masing alternatif strategi.

Tabel 4. Matriks QSPM

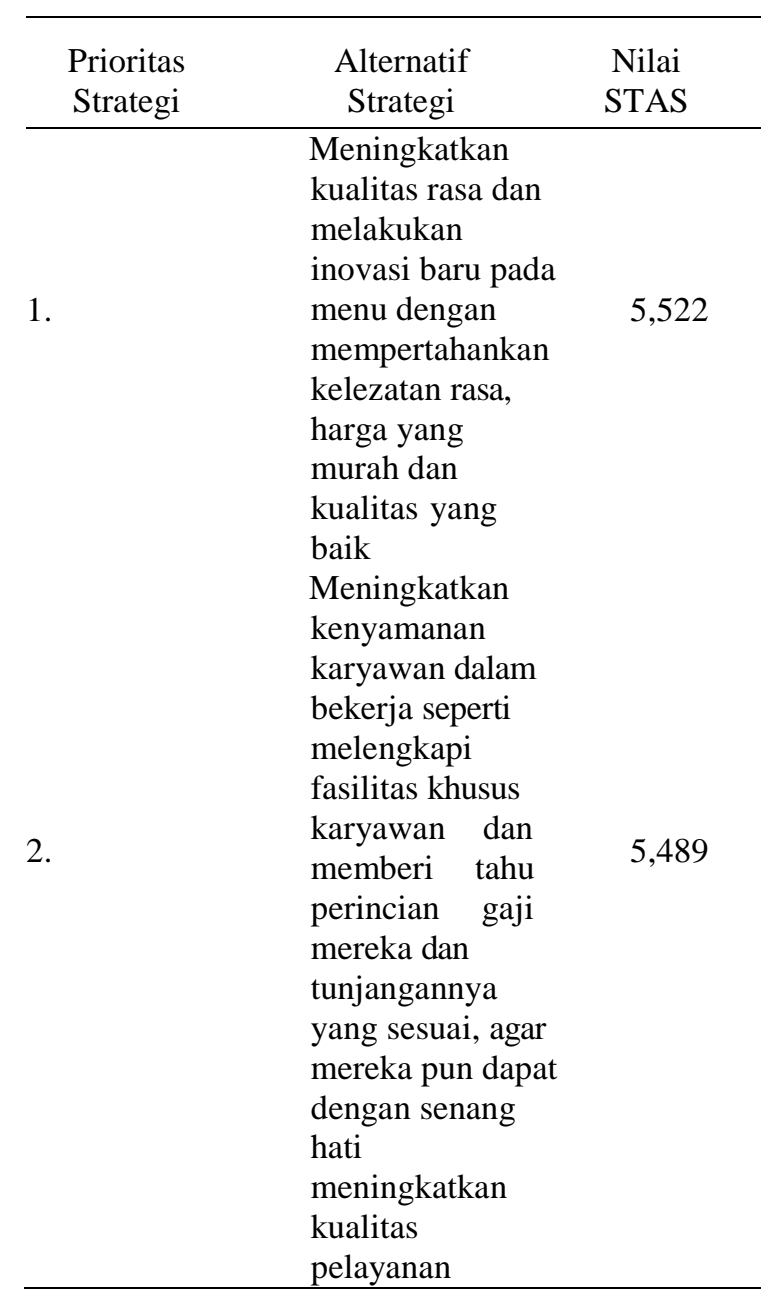

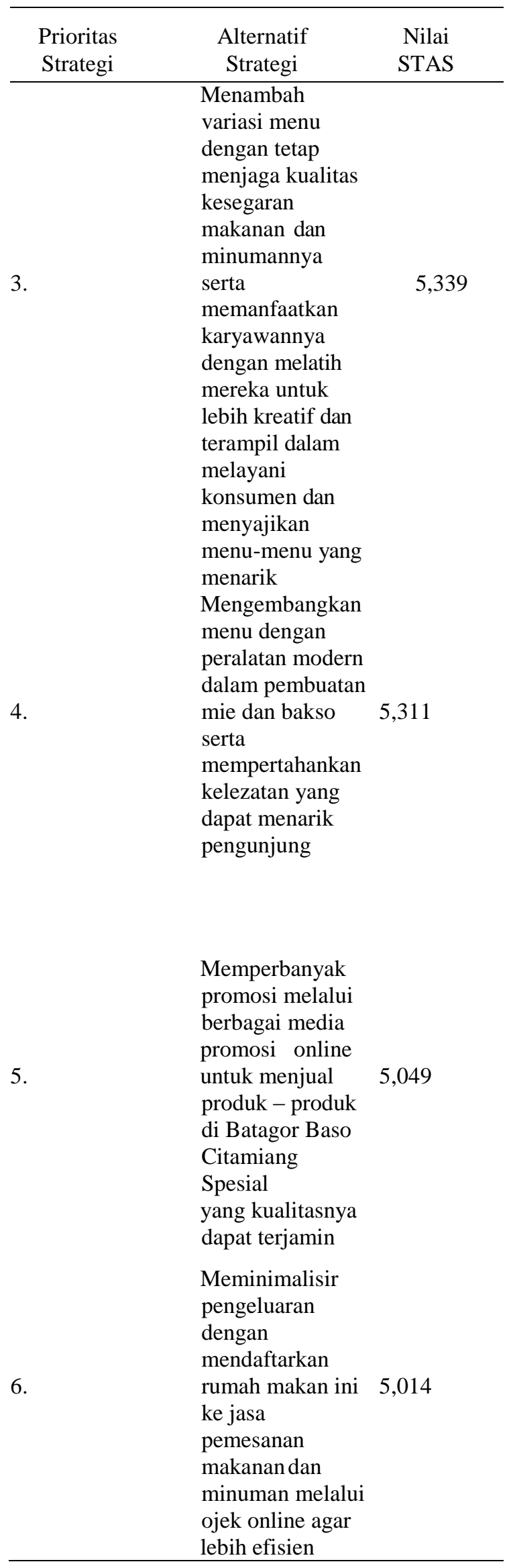




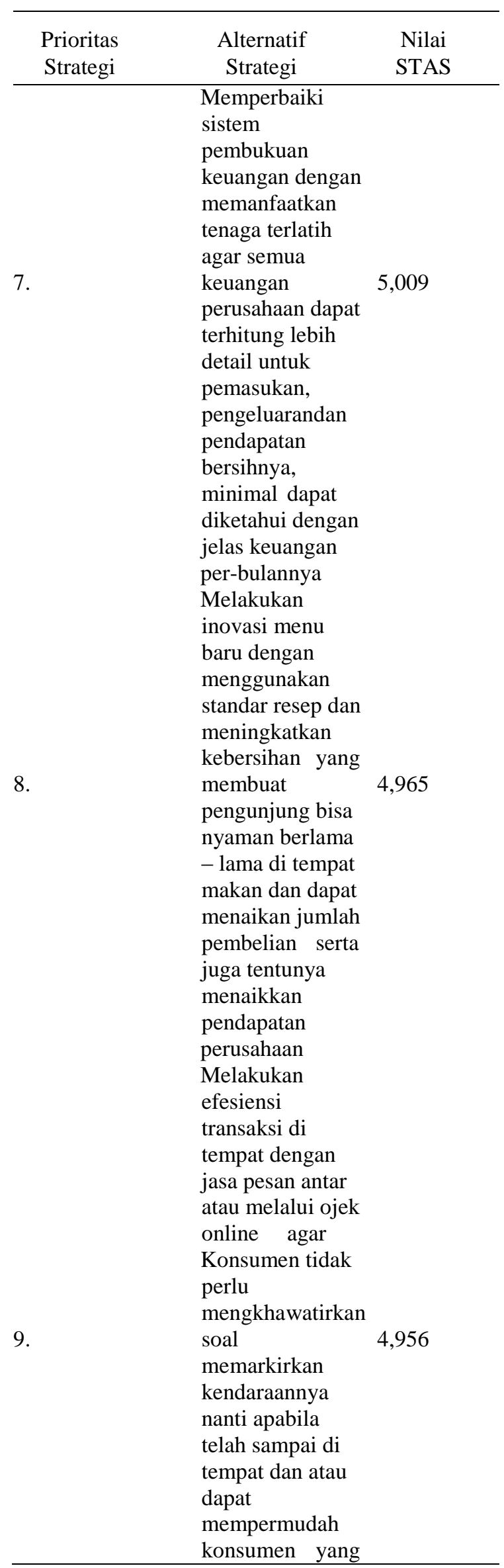

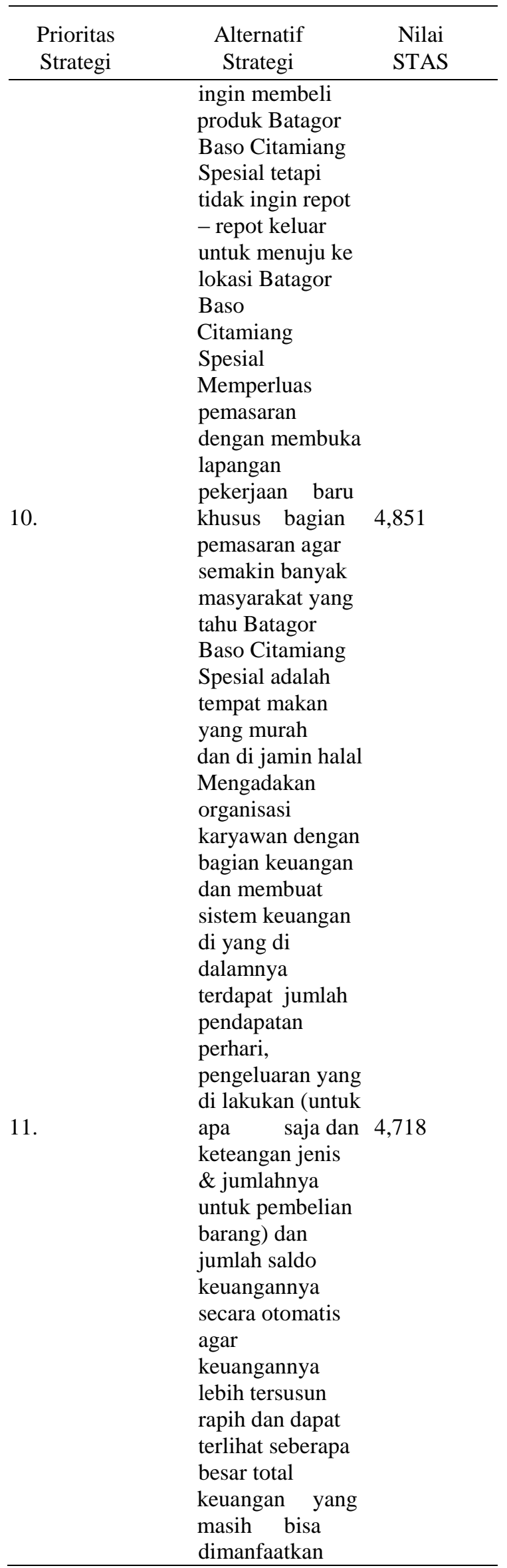




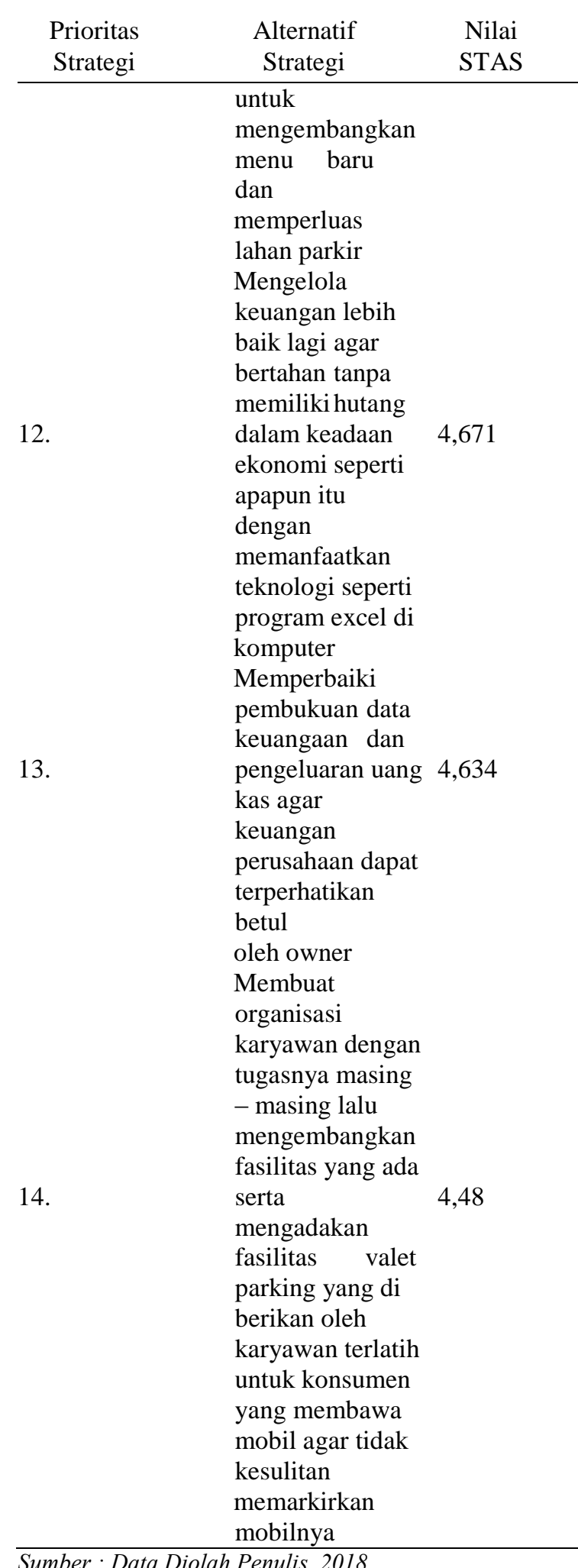

\section{Kesimpulan}

Berdasarkan dari analisi lingkunagn internal dan eksternal dengan bantuan beberapa alat seperti matriks IFAS \& EFAS, matriks IE, Matriks SWOT dan yang terakhir adalah matriks QSPM, di dapatkan kesimpulan sebagai berikut.

Dari hasil analisis internal, Batagor Baso Citamiang Spesial memiliki beberapa kekuatan seperti yang paling utamanya adalah harga yang murah, rasa yang lezat, memiliki target pasar yang luas, kualitas produk baik karena masih terlihat fresh saat di sajikan, memiliki standar resep, memiliki kebijakan untuk karyawannya, memiliki pelayanan yang ramah, luasnya peluang kerja, tidak memiliki hutang kepada pihak mana pun dan memiliki tempat penyimpanan bahan makanan dan minuman seperti chiller \& freezer agar bahan makanan dan minuman tetap terjaga. Untuk kelemahan utama yang dimiliki Batagor Baso Citamiang Spesial, adalah fasilitas yang agak kurang memenuhi kebutuhan konsumen, penulisan pendapatan per-hari, per-bulan dan per- tahunnya masih di tulis tangan dalam sebuah buku, tidak ada organisasi karyawan dan tidak memiliki ketetapan sanksi pada setiap poin - poin peraturan karyawan jika ada yang melanggar.

Untuk hasil analisis eksternal dari Batagor Baso Citamiang Spesial yang di bagi menjadi peluang dan ancaman. Peluang utama yang dimiliki oleh rumah makan ini adalah sudah memiliki SIUP dan Sertifikat Halal dan naik turunnya perekonomian di Kota Bandung tidak berpengaruh besar terhadap keuangan bisnis ini. Ada pun ancaman yang dimiliki Batagor Baso Citamiang Spesial ini yang utamanya adalah belum melakukan inovasi makanan dan minuman kembali secara rutin dan belum bergabung dengan pemesanan dari jasa ojek online yang dapat memudahkan konsumen dalam melakukan pemesanan. Peluang dan ancaman tersebut dapat di gunakan sebagai pertimbangan untuk menyusun sebuah strategi perushaan.

Setelah menganalisis menggunakan beberapa alat bantu matriks IFAS \& EFAS, matriks IE, matriks SWOT dan matriks QSPM, memunculkan sebuah hasil berupa strategi alternatif yang dapat di terapkan di 
Batagor Baso Citamiang Spesial ini. Alternatif strategi yang menjadi prioritas adalah "Meningkatkan kualitas rasa dan melakukan inovasi baru pada menu dengan mempertahankan kelezatan rasa, harga yang murah dan kualitas yang baik" dengan nilai STAS terbesar adalah 5,522 berdasarkan hasil dari perhitungan dengan matriks QSPM.

\section{Daftar Pustaka}

Kotler, Philip. 2002. Manajemen Pemasaran. Jakarta: Prenhallindo

Hariadi, Doni., Soebari Martoatmodjo. 2013. Pengaruh Produk, Harga, Promosi, dan Distribusi Terhadap Keputusan Pembelian Konsumen Pada Produk Projector Microvision. Jurnal Ilmu dan Riset Manajemen Volume 1 Nomor 1, Sekolah Tinggi Ilmu Ekonomi Indonesia (STIESIA). Surabaya

Sugiyono. 2009. Metode Penelitian Bisnis. Bandung : CV Alfabeta.

Sugiyono. 2012. Metode Penelitian Kuantitatif, Kualitatif, dan $R \& D$. Cetakan ke 17. Bandung: Alfabeta.

Rangkuti, Freddy. 2014. Analisis SWOT Teknik Membedah Kasus Bisnis. Jakarta: PT Gramedia Pustaka Utama. 